\title{
Phytoglobin: a novel nomenclature for plant globins accepted by the globin community at the 2014 XVIII conference on
} Oxygen-Binding and Sensing Proteins [version 1; peer review:

\section{2 approved]}

\author{
Robert Hill11, Mark Hargrove22, Raúl Arredondo-Peter³ \\ ${ }^{1}$ Department of Plant Science, University of Manitoba, Winnipeg, Canada \\ ${ }^{2}$ Molecular Biology Building, Department of Biochemistry, Biophysics \& Molecular Biology, Iowa State University, Ames, USA \\ ${ }^{3}$ Laboratorio de Biofísica y Biología Molecular, Centro de Investigación en Dinámica Celular, Instituto de Investigación en Ciencias \\ Básicas y Aplicadas, Universidad Autónoma del Estado de Morelos, Cuernavaca, Morelos, Mexico
}

V1 First published: 24 Feb 2016, 5:212

https://doi.org/10.12688/f1000research.8133.1

Latest published: 24 Feb 2016, 5:212

https://doi.org/10.12688/f1000research.8133.1

\section{Abstract}

Hemoglobin $(\mathrm{Hb})$ is a heme-containing protein found in the red blood cells of vertebrates. For many years, the only known Hb-like molecule in plants was leghemoglobin (Lb). The discovery that other $\mathrm{Hb}$-like proteins existed in plants led to the term "nonsymbiotic Hbs (nsHbs)" to differentiate them from the Lbs. While this terminology was adequate in the early stages of research on the protein, the complexity of the research in this area necessitates a change in the definition of these proteins to delineate them from red blood cell $\mathrm{Hb}$. At the 2014 XVIII Conference on Oxygen-Binding and Sensing Proteins, the group devoted to the study of heme-containing proteins, this issue was discussed and a consensus was reached on a proposed name change. We propose Phytoglobin (Phytogb) as a logical, descriptive name to describe a heme-containing ( $\mathrm{Hb}$-like) protein found in plants. It will be readily recognized by the research community without a prolonged explanation of the origin of the term. The classification system that has been established can essentially remain unchanged substituting Phytogb in place of nsHb. Here, we present a guide to the new nomenclature, with reference to the existing terminology and a phylogenetic scheme, placing the known Phytogbs in the new nomenclature.

\section{Keywords}

Algae, angiosperms, bryophytes, gymnosperms, legumes, nonsymbiotic, truncated

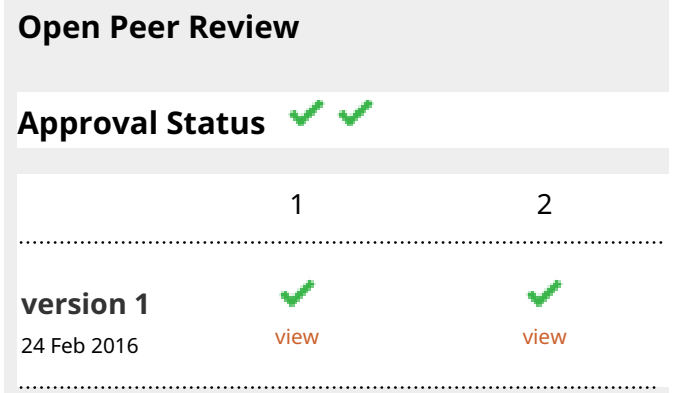

\section{Alexey F. Topunov, Research Center of Biotechnology of the Russian Academy of Sciences, Moscow, Russian Federation \\ 2. Kurt V Fagerstedt, University of Helsinki, Helsinki, Finland \\ Any reports and responses or comments on the article can be found at the end of the article.}


OQBiP

This article is included in the Oxygen-binding

and sensing proteins collection.

This article is included in the Iowa State

IOWA STATE

UNIVERSITY University collection.

Corresponding author: Raúl Arredondo-Peter (ra@uaem.mx)
Competing interests: No competing interests were disclosed.

Grant information: The author(s) declared that no grants were involved in supporting this work.

Copyright: ( 2016 Hill R et al. This is an open access article distributed under the terms of the Creative Commons Attribution License, which permits unrestricted use, distribution, and reproduction in any medium, provided the original work is properly cited.

How to cite this article: Hill R, Hargrove $M$ and Arredondo-Peter R. Phytoglobin: a novel nomenclature for plant globins accepted by the globin community at the 2014 XVIII conference on Oxygen-Binding and Sensing Proteins [version 1; peer review: 2 approved] F1000Research 2016, 5:212 https://doi.org/10.12688/f1000research.8133.1

First published: 24 Feb 2016, 5:212 https://doi.org/10.12688/f1000research.8133.1 
Hemoglobin $(\mathrm{Hb})$ is a heme-containing protein found in the red blood cells of vertebrates ${ }^{1}$. Hemoglobin-like proteins are also found in other tissues of vertebrates where they are given tissue-specific names that help to identify their locations and distinguish them from red blood cell $\mathrm{Hb}^{2,3}$. For many years, the only known Hb-like molecule in plants was leghemoglobin (Lb), a protein induced as a result of the symbiotic relationship between legume plants and nitrogen-fixing bacteria ${ }^{4}$. The discovery that other $\mathrm{Hb}$-like proteins existed in plants not capable of symbiotic relationships led to the term "nonsymbiotic Hbs (nsHbs)" to differentiate them from the Lbs $^{5}$. While this terminology was adequate in the early stages of research on the protein, the complexity of the research in this area necessitates a change in the definition of these proteins to delineate them from red blood cell $\mathrm{Hb}$, in keeping with the terminology for other Hb-like proteins, such as myoglobin in muscle, neuroglobin in neuron tissue and cytoglobin in vertebrate cell cytoplasm ${ }^{2,3}$. In 2001 Hunt et al. ${ }^{6}$ classified plant Hbs as globin (GLB)0, GLB1, GLB2, GLb3 and GLBS corresponding to undetermined (mostly liverwort and moss) nsHbs, angiosperm nsHbs class/type 1 and nsHbs class/type 2, truncated Hbs and symbiotic Hbs (which included
Lbs), respectively. However, an epithet for plant Hbs was absent in this nomenclature and distinctive characteristics for each category were not fully defined resulting in an incomplete classification system.

At the 2014 XVIII Conference on Oxygen-Binding and Sensing Proteins, the group devoted to the study of heme-containing proteins, the above issue was discussed and a consensus was reached on a proposed name change. Phytoglobin (phyto, plant; globin, hemecontaining protein folding structurally similar to the sperm whale myoglobin structure whose heme-Fe is invariably coordinated at the proximal site by His F8), abbreviated as Phytogb, was proposed as a logical, descriptive name to describe a heme-containing (Hb-like) protein found in plants. It will be readily recognized by the research community without a prolonged explanation of the origin of the term, as is the case for 'nonsymbiotic hemoglobin'. The classification system that has been established can essentially remain unchanged substituting Phytogb in place of nsHb. A guide to the new nomenclature, with reference to the existing terminology, is given in Table 1. A more detailed phylogenetic scheme, placing the known Phytogbs in the new nomenclature, is shown in Figure 1.

Table 1. System and characteristics of the accepted nomenclature for plant (algae + land plants) Phytoglobins (Phytogb).

\begin{tabular}{|c|c|c|c|}
\hline $\begin{array}{l}\text { Former plant globin } \\
\text { name and abbreviation } \\
\text { (in parenthesis) }\end{array}$ & $\begin{array}{l}\text { New } \\
\text { nomenclature }\end{array}$ & Plant origin & Distinctive characteristics ${ }^{b}$ \\
\hline $\begin{array}{l}\text { Nonsymbiotic hemoglobin } \\
\text { (nsHb) }\end{array}$ & Phytogb0 & $\begin{array}{l}\text { Algae }^{c}+\text { bryophytes+ } \\
\text { gymnosperms }\end{array}$ & $\begin{array}{l}\text { Heme-Fe either penta- or hexacoordinate. } \\
\text { Moderate to high affinity for } \mathrm{O}_{2} \text {. } \\
\text { Localized in any plant organ. }\end{array}$ \\
\hline $\begin{array}{l}\text { Class/type } 1 \\
\text { nonsymbiotic hemoglobin } \\
\text { (nsHb-1) }\end{array}$ & Phytogb1 & Angiosperms & $\begin{array}{l}\text { Heme-Fe predominantly hexacoordinated by a distal } \\
\text { amino acid. } \\
\text { Extremely high affinity for } \mathrm{O}_{2} \text { mostly due to a very low } \\
\mathrm{O}_{2} \text {-dissociation rate constant }\left(k_{\text {off }}\right) \text {. } \\
\text { Localized in any plant organ. }\end{array}$ \\
\hline $\begin{array}{l}\text { Class/type } 2 \\
\text { nonsymbiotic hemoglobin } \\
\text { (nsHb-2) }\end{array}$ & Phytogb2 & Angiosperms & $\begin{array}{l}\text { Heme-Fe predominantly pentacoordinated. } \\
\text { Moderate to high affinity for } \mathrm{O}_{2} \text {. } \\
\text { Localized in any plant organ. }\end{array}$ \\
\hline $\begin{array}{l}\text { Symbiotic hemoglobin } \\
(\text { symHb) }\end{array}$ & SymPhytogb & $\begin{array}{l}\text { Non-legume } \mathrm{N}_{2} \text {-fixing } \\
\text { plants }^{\mathrm{d}}\end{array}$ & $\begin{array}{l}\text { Heme-Fe predominantly pentacoordinated. } \\
\text { Moderate to high affinity for } \mathrm{O}_{2} \text {. } \\
\text { Specifically localized in } \mathrm{N}_{2} \text {-fixing nodules of actinorhizal } \\
\text { plants or any other non-legume land plant }\end{array}$ \\
\hline $\begin{array}{l}\text { Leghemoglobin } \\
\text { (Lb) }\end{array}$ & Lb & $\mathrm{N}_{2}$-fixing legumes ${ }^{d}$ & $\begin{array}{l}\text { Heme-Fe predominantly pentacoordinate. } \\
\text { Moderate to high affinity for } \mathrm{O}_{2} \text {. } \\
\text { Specifically localized in legume } \mathrm{N}_{2} \text {-fixing nodules. }\end{array}$ \\
\hline $\begin{array}{l}\text { Class/type } 3 \\
\text { nonsymbiotic hemoglobin/ } \\
\text { Truncated hemoglobin } \\
\text { (tHb) }\end{array}$ & Phytogb3 & Algae $^{c}+$ land plants & $\begin{array}{l}\text { Globin-domain amino acid sequence and structure } \\
\text { (i.e. folding into the } 2 / 2 \text {-fold) similar to those of bacterial } \\
\text { tHbs. } \\
\text { Heme-Fe either penta- or hexacoordinate. } \\
\text { Moderate to high affinity for } \mathrm{O}_{2} \text {. } \\
\text { Localized in any plant organ. }\end{array}$ \\
\hline
\end{tabular}

aNumerical classification corresponds to that previously proposed by Hunt et al. ${ }^{6}$. Proteins coded by multiple phytogb gene copy numbers within the same plant species should be indicated as the number of copy after the Phytogb numerical classification. For example, rice (Oryza sativa) Phytogbs 1 and 2 (corresponding to the former ns Hbs-1) should be indicated as rice Phytogb1.1 and Phytogb1.2, respectively (see text for a description on the species-specific Phytogbs acronym).

${ }^{b} \mathrm{Heme}-\mathrm{Fe}$ coordination and affinity for $\mathrm{O}_{2}$ correspond to those from moss Phytogb0 ${ }^{7-9}$, barley ${ }^{10}$, rice ${ }^{11}$ and Arabidopsis ${ }^{12}$ Phytogb1, Arabidopsis Phytogb2 ${ }^{12}$, Casuarina SymPhytogb ${ }^{13}$, soybean $\mathrm{Lb}^{14,15}$ and Arabidopsis Phytogb316 representative of Phytogb0, Phytogb1, Phytogb2, SymPhytogb, $\mathrm{Lb}$ and Phytogb3, respectively.

${ }^{c}$ Amino acid sequence of algal globins analyzed so far ${ }^{17-19}$ is similar to that of land plant Phytogb0 and Phytogb3, hence algal globins can be classified as Phytogb0 or Phytogb3, respectively.

${ }^{d}$ Some SymPhytogbs and Lbs (such as the Parasponia ${ }^{20}$ and Casuarina ${ }^{21}$ and Chamaecrista ${ }^{22}$ globins, respectively) are intermediate between Phytogbs1 and Phytogbs2 and SymPhytogbs and Lbs L $2,23^{2}$ because they exhibit amino acid sequence similarity to Phytogbs1 and Phytogbs2 (Figure 1) and are localized in non-legume an legume nodules and apparently play a role in symbiotic $\mathrm{N}_{2}$-fixation. 


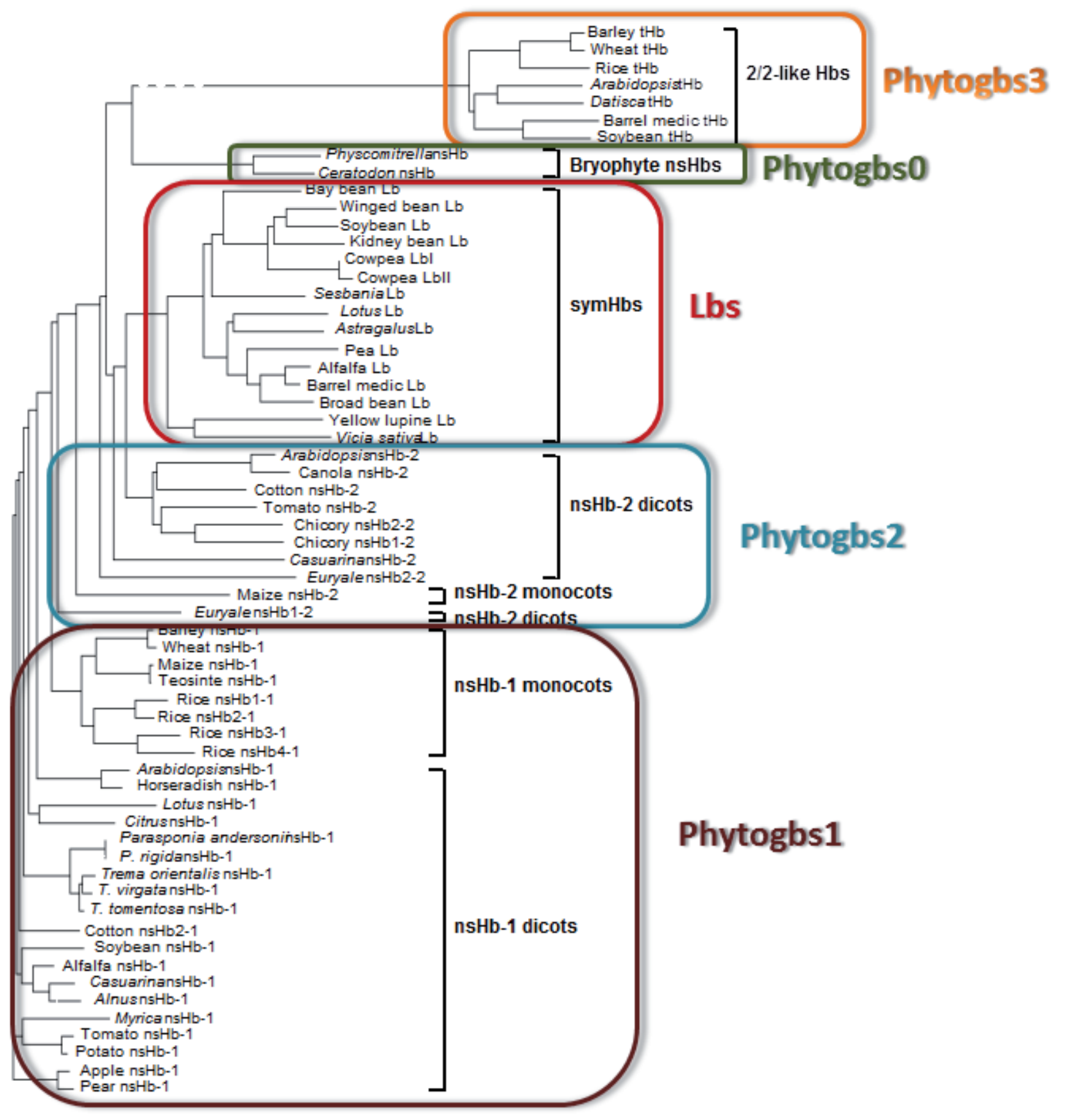

Figure 1. Phylogenetic representation of the novel nomenclature for land plant Phytogbs. Note that Parasponia, Casuarina, Alnus and Myrica SymPhytogbs are intermediate between SymPhytogbs and Phytogbs1 and Phytogbs2 (see Table 1 for explanation). Figure modified from Garrocho-Villegas et al. ${ }^{23}$ (reprinted with permission). 
Also, we propose that acronym for the species-specific Phytogbs corresponds to the first three binomial (i.e. genus and species) letters followed by the Phytogb type and phytogb number of copy. For example, the acronym for rice (Oryza sativa) Phytogb1.1 (see Table 1) corresponds to OrysatPhytogb1.1.

\section{Author contributions}

RDH conceived the proposal. RDH, MSH and RAP discussed and proposed the novel nomenclature, prepared the first draft of the manuscript, revised the draft manuscript and have agreed to the final content.

\section{Competing interests}

No competing interests were disclosed.

\section{Grant information}

The author(s) declared that no grants were involved in supporting this work.

\section{Acknowledgements}

Authors wish to express their gratitude to Itzel Rojas Sánchez, Gisselle A. Fuentes and Gustavo Rodríguez-Alonso for evaluating the Phytoglobins nomenclature presented here and providing useful comments.
1. Dickerson RE, Geis I: Hemoglobin: structure, function, evolution, and pathology. Menlo Park, California: The Benjamin/Cummings Pub. Co., Inc.; 1983; 176. Reference Source

2. Vinogradov $\mathrm{SN}$, Hoogewijs $\mathrm{D}$, Bailly $\mathrm{X}$, et al.: A phylogenomic profile of globins BMC Evol Biol. 2006; 6: 31

PubMed Abstract | Publisher Full Text | Free Full Text

3. Weber RE, Vinogradov SN: Nonvertebrate hemoglobins: functions and molecular adaptations. Physiol Rev. 2001; 81(2): 569-628. PubMed Abstract

4. Appleby CA: Leghemoglobin and Rhizobium respiration. Annu Rev Plant Physiol. 1984: 35: 443-478. Publisher Full Text

5. Bogusz D, Appleby CA, Landsmann J, et al.: Functioning haemoglobin genes in non-nodulating plants. Nature 1988; 331(6152): 178-180. PubMed Abstract | Publisher Full Text

6. Hunt PW, Watts RA, Trevaskis B, et al.: Expression and evolution of functionally distinct haemoglobin genes in plants. Plant Mol Biol. 2001; 47(5): 677-692. PubMed Abstract | Publisher Full Text

7. Garrocho-Villegas V, Arredondo-Peter R: Molecular cloning and characterization of a moss (Ceratodon purpureus) non-symbiotic hemoglobin provides insight into the early evolution of plant non-symbiotic hemoglobins. Mol Biol Evol. 2008; 25(7): 1482-1487. PubMed Abstract | Publisher Full Text

8. Smagghe BJ, Kundu S, Hoy JA, et al.: Role of phenylalanine B10 in plant non-symbiotic hemoglobins. Biochemistry. 2006; 45(32): 9735-9745. PubMed Abstract | Publisher Full Text

9. Vázquez-Limón C, Castro-Bustos S, Arredondo-Peter R: Spectroscopic analysis of moss (Ceratodon purpureus and Physcomitrella patens) recombinant non-symbiotic hemoglobins. Commun Integr Biol. 2012; 5(6): 527-530. PubMed Abstract | Publisher Full Text

10. Duff SM, Wittenberg JB, Hill RD: Expression, purification, and properties of recombinant barley (Hordeum sp.) hemoglobin. Optical spectra and reactions with gaseous ligands. J Biol Chem. 1997; 272(27): 16746-16752. PubMed Abstract | Publisher Full Text

11. Arredondo-Peter R, Hargrove MS, Sarath G, et al.: Rice hemoglobins. Gene cloning, analysis, and O2-binding kinetics of a recombinant protein synthesized in Escherichia coli. Plant Physiol. 1997; 115(3): 1259-1266. PubMed Abstract | Publisher Full Text

12. Trevaskis $B$, Watts RA, Andersson SR, et al:: Two hemoglobin genes in Arabidopsis thaliana: the evolutionary origins of leghemoglobins. Proc Nat Acad Sci USA. 1997; 94(22): 12230-12234. PubMed Abstract | Free Full Text

13. Fleming Al, Wittenberg JB, Wittenberg BA, et al:: The purification, characterization and ligand-binding kinetics of hemoglobins from root nodules of the non-leguminous Casuarina glauca-Frankia symbiosis. Biochim Biophys Acta. 1987; 911(2): 209-220. Publisher Full Text

14. Hargrove MS, Barry JK, Brucker EA, et al.: Characterization of recombinant soybean leghemoglobin a and apolar distal histidine mutants. J Mol Biol. 1997; 266(5): 1032-1042. PubMed Abstract | Publisher Full Text

15. Wittenberg JB, Appleby CA, Wittenberg BA: The kinetics of the reactions of leghemoglobin with oxygen and carbon monoxide. J Biol Chem. 1972; 247(2): 527-31. PubMed Abstract

16. Watts RA, Hunt PW, Hvitved AN, et al:: A hemoglobin from plants homologous to truncated hemoglobins of microorganisms. Proc Natl Acad Sci USA. 2001; 98(18): 10119-10124.

PubMed Abstract | Publisher Full Text | Free Full Text

17. Fernández I, Vinogradov SN, Arredondo-Peter R: Identification and in silico characterization of a putative ancestor to land plant non-symbiotic hemoglobins from the prasinophyceae algae Micromonas and Ostreococcus. Global J Biochem. 2010; 1: 18-30. Reference Source

18. Vinogradov SN, Fernández I, Hoogewijs D, et al:: Phylogenetic relationships of $3 / 3$ and 2/2 hemoglobins in Archaeplastida genomes to bacterial and other eukaryote hemoglobins. Mol Plant. 2011; 4(1): 42-58. PubMed Abstract | Publisher Full Tex

19. Vinogradov SN, Hoogewijs D, Arredondo-Peter R: What are the origins and phylogeny of plant hemoglobins? Commun Integr Biol. 2011; 4(4): 443-445. PubMed Abstract | Free Full Text

20. Appleby CA, Tjepkema JD, Trinick MJ: Hemoglobin in a nonleguminous plant, Parasponia: possible genetic origin and function in nitrogen fixation. Science. 1983; 220(4600): 951-953.

PubMed Abstract | Publisher Full Text

21. Jacobsen-Lyon K, Jensen EO, Jørgensen JE, et al:: Symbiotic and non-symbiotic hemoglobin genes of Casuarina glauca. Plant Cell. 1995; 7(2): 213-223. PubMed Abstract | Publisher Full Text | Free Full Text

22. Gopalasubramaniam SK, Kovacs F, Violante-Mota F, et al: Cloning and characterization of a caesalpinoid (Chamaecrista fasciculata) hemoglobin: the structural transition from a nonsymbiotic hemoglobin to a leghemoglobin. Proteins. 2008; 72(1): 252-260. PubMed Abstract | Publisher Full Text

23. Garrocho-Villegas V, Gopalasubramaniam SK, Arredondo-Peter R: Plant hemoglobins: what we know six decades after their discovery. Gene. 2007, 398(1-2): 78-85.

PubMed Abstract | Publisher Full Tex 


\section{Open Peer Review}

\section{Current Peer Review Status:}

\section{Version 1}

Reviewer Report 11 March 2016

https://doi.org/10.5256/f1000research.8749.r12637

(C) 2016 Fagerstedt $\mathbf{K}$. This is an open access peer review report distributed under the terms of the Creative Commons Attribution License, which permits unrestricted use, distribution, and reproduction in any medium, provided the original work is properly cited.

\section{Kurt V Fagerstedt}

Department of Biosciences, University of Helsinki, Helsinki, Finland

The change in the hemoglobin/phytoglobin nomenclature presented in Hill et al. paper is timely and well supported by the hemoglobin and phytoglobin community. The change has been discussed in many conferences including the 2014 XVIII Conference on Oxygen-Binding and Sensing Proteins mentioned in the paper. The system presented in Table 1 is logical and supported by the protein structures and by the phylogenetic tree presented in Figure 2 . The only and very slight problem is in the positioning of symbiotic hemoglobins present in non-legume nitrogen fixing plants, which have amino acid sequence similarities with both Phytogbs 1 and 2 . However, their positioning as a separate group in Table 1 is supported by the fact that they are only found in the nodules of actinorhizal plants.

Dr. Topunov has provided a historical perspective on the evolution of the name phytoglobin in his referee report, which clearly shows both the need for the term and no scientific discrepancy in its use. I agree wholeheartedly.

Competing Interests: No competing interests were disclosed.

I confirm that I have read this submission and believe that I have an appropriate level of expertise to confirm that it is of an acceptable scientific standard.

Author Response 11 Mar 2016

Raul Arredondo-Peter, Universidad Autónoma del Estado de Morelos, Cuernavaca, Morelos, Mexico

We thank Dr. Fagerstedt for evaluating this article and his comments.

Competing Interests: No competing interests were disclosed. 
Reviewer Report 08 March 2016

https://doi.org/10.5256/f1000research.8749.r12635

(C) 2016 Topunov A. This is an open access peer review report distributed under the terms of the Creative Commons Attribution License, which permits unrestricted use, distribution, and reproduction in any medium, provided the original work is properly cited.

\section{Alexey F. Topunov}

Bach Institute of Biochemistry, Research Center of Biotechnology of the Russian Academy of Sciences, Moscow, Russian Federation

The reviewing article is dedicated to very interesting and actual issue. After proposition of the term "leghemoglobin" (Lb) by Virtanen and Laine (1946) ${ }^{1}$ it was used only for hemoglobins ( $\mathrm{Hb}$ ) of the leguminous plants because it was the only one group of plants known to contain $\mathrm{Hb}$. However after observing of $\mathrm{Hbs}$ in non-leguminous plants (Appleby et al. $1983^{2}$, Tjepkema $1983^{3}$ ) the ironic situation originated. "Non-leguminous" hemoglobins are evolutionary closer to leghemoglobins, but according to their denominations they looked to be similar to animal ones. Even hemoglobin of cyanobacteria received its own specific denomination "cyanoglobin" (Hill et al 1996) ${ }^{4}$ although it was initially illogically named "Myogloblin in a cyanobacterium" (Potts et al 1992) ${ }^{5}$, but plant Hbs were poor relatives in this family. The necessity of new terminology for plant hemoglobins appeared and such thoughts apparented and were discussed.

The proposition of the new terminology "phytoglobin" (Phb) was already once stated. It was made in Bach Institute of Biochemistry (Moscow, Russia) in the book by Kretovich ${ }^{6}$ and this term was even used in the published article (Topunov 1994) ${ }^{7}$. This idea was not further developed at that time and in the next paper (Topunov 1995) ${ }^{8}$ the old word "leghemoglobin" was employed again but using of the "phytoglobin" terminology in the article ${ }^{7}$ was referred.

In conclusion: it is the right desire to revive this terminology for plant hemoglobins and it has to be promoted and continued. There is the one difference between these two propositions of the "phytoglobin" term. In 1990s it was used as the general terminology for all plant hemoglobins (from both leguminous and non-leguminous plants) ${ }^{6,7}$ so "leghemoglobin" term could be excluded. Now it is proposed for plant hemoglobins aside from $\mathrm{Lb}$, and it looks more pragmatic because scientists are accustomed to the "leghemoglobin" term and there is no need to exclude it from the scientific practice.

\section{References}

1. VIRTANEN AI, LAINE T: Red, brown and green pigment in leguminous root nodules.Nature. 1946; 157: 25 PubMed Abstract

2. Appleby CA, Tjepkema JD, Trinick MJ: Hemoglobin in a nonleguminous plant, parasponia: possible genetic origin and function in nitrogen fixation.Science. 1983; 220 (4600): 951-3 PubMed Abstract | Publisher Full Text

3. Tjepkema JD: Hemoglobin in the nitrogen fixing root nodules of actinorhizal plants. Can J Bot. 1983; 61 (11): 2924-2929

4. Hill DR, Belbin TJ, Thorsteinsson MV, Bassam D, et al.: GlbN (cyanoglobin) is a peripheral membrane protein that is restricted to certain Nostoc spp.J Bacteriol. 1996; 178 (22): 6587-98 PubMed Abstract 
5. Potts M, Angeloni SV, Ebel RE, Bassam D: Myoglobin in a cyanobacterium.Science. 1992; 256 (5064): 1690-1 PubMed Abstract

6. Kretovich WL: The Assimilation and Metabolism of Nitrogen in Plants [in Russian]. Nauka, Moscow. 1987.

7. Topunov AF: Function of phytoglobin in legume nodules and the regulation of oxygen conditions. Appl Biochem Microbiol. 1994; 30 (1): 1-12

8. Topunov AF: Leghemoglobin and its role in regulation of oxygen concentration in nitrogenfixing legume nodules. Biochemistry (Moscow). 1995; 60 (1): 45-49

Competing Interests: No competing interests were disclosed.

I confirm that I have read this submission and believe that I have an appropriate level of expertise to confirm that it is of an acceptable scientific standard.

Author Response 08 Mar 2016

Raul Arredondo-Peter, Universidad Autónoma del Estado de Morelos, Cuernavaca, Morelos, Mexico

We thank Dr. Topunov for his evaluation and providing information that complements the contents of this article.

Competing Interests: No competing interests were disclosed.

The benefits of publishing with F1000Research:

- Your article is published within days, with no editorial bias

- You can publish traditional articles, null/negative results, case reports, data notes and more

- The peer review process is transparent and collaborative

- Your article is indexed in PubMed after passing peer review

- Dedicated customer support at every stage

For pre-submission enquiries, contact research@f1000.com 